\title{
Mass media and the premarital sexual behaviour of the adolescents in Imo State, Nigeria
}

\section{K. O. Nworgu}

Imo State University. Department of Mass Communication. Owerri, Nigeria. Email: konworgu@gmail.com.

\begin{abstract}
The authors set to investigate the influence of the Mass Media on adolescents' knowledge of and behavior towards sex and sexuality, especially, regarding early sex, the use of contraceptives and condoms. The participants were drawn from five secondary schools in Owerri Municipality, the Capital of Imo State, Nigeria. The simple size included 100 respondents made up of males and females between the ages of 10 and 19 years drawn from simple random sampling. Questionnaire containing semistructured (close-ended) questions. Interview sessions involving media workers form select radio, television and newspaper houses in Owerri were conducted. Three research questions and one hypothesis were used to straighten the study. Results showed the respondents mean age for first sex is 17.8 years. The findings show that the media did not have very significant influence at 0.05 on adolescents' sexual behavior, especially, as regards, having first sex experience. This result is explained by the fact that most the respondents lived in boarding hostels and may not have access to media, while in school. It was recommended the influence of family members, including parents and peer groups should be given priority attention when adolescent sexual behavior is discussed, especially, in Nigeria where extended family members play a vital role in the socialization of the adolescents.
\end{abstract}

Keywords: Adolescent; Sex; Sexuality behavior; Mass media.

Resumo. Meios de comunicação de massa e comportamento sexual antes do casamento de adolescentes no Estado de Imo, Nigéria. $\mathrm{O}$ autor propõe a investigar a influência da mídia de massa no conhecimento e comportamento dos adolescentes em relação ao sexo e à sexualidade, especialmente em relação ao sexo precoce, ao uso de contraceptivos e preservativos. Os participantes foram selecionados de cinco escolas secundárias no Município de Owerri, capital do Estado de Imo, na Nigéria. O tamanho simples da amostra incluiu 100 entrevistados, constituídos por homens e mulheres com idades entre 10 e 19 anos, provenientes de amostragem aleatória simples. 0 questionário continha perguntas semiestruturadas (fechadas). Foram realizadas sessões de entrevistas envolvendo trabalhadores da mídia de algumas casas de rádio, televisão e
Received

Mar. 10, 2020

Accepted

Oct. 26,2020

Available on line

Oct. 27, 2020

Release

Dec. 31,2020

Open access

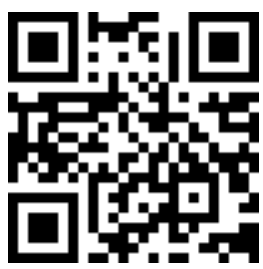

ORCID

(D) 0000-0002-4626-7726 K. O. Nworgu

ISSN 2359-1412/RBGAS-2020-0019/2020/7/17/16/1257

Rev. Bras. Gest. Amb. Sustent.

http://revista.ecogestaobrasil.net 
jornal em Owerri. Três questões da pesquisa e uma hipótese foram usadas para direcionar o estudo. Os resultados mostraram que a idade média do primeiro sexo é de 17,8 anos. As descobertas mostram que a mídia não teve uma influência muito significativa de 0,05 no comportamento sexual dos adolescentes, especialmente no que diz respeito à experiência com o primeiro sexo. Este resultado é explicado pelo fato de que a maioria dos entrevistados morava em albergues e pode não ter acesso à mídia enquanto estava na escola. Foi recomendado que a influência dos membros da família, incluindo pais e grupos de casais, deveria receber atenção prioritária quando se discute o comportamento sexual dos adolescentes, especialmente na Nigéria, onde os membros da família estendida desempenham um papel vital na socialização dos adolescentes.

Palavras-chave: Adolescente; Sexo; Comportamento de sexualidade; Meios de comunicação em massa.

\section{Introduction}

In Nigeria, adolescents (aged 10-19 years) were estimated in 1997 to number 18.8 million out of a total estimated population of 104.4 million (Akinfeleye et al., 1998) and 22.5 million in the year 2003 at 3\% annual growth rate. Adolescents are individuals undergoing a critical period of passage to adulthood, whose central biological event is puberty. The period of adolescence is a time of new experience as young people begin to experiment to master skills and responsibilities and face-up to the demands of adult life. It is a period of transition from a community of non-sexually active to that of sexually active beings and is associated with some problems of adjustment. Their sexual behavior or lack of it poses a problem, not only to themselves but also to their parents and society at large. Hence, the mass media role in adolescents' sexuality in this context is seen as the disposition of the young people towards sex, sex-related issues and sex materials such as pornographic films, contraceptives and the use of condom as may be contented in radio, television, newspaper or internet. Also, adolescents' sexuality or sexual behaviour has manifested in severe negative repercussions on their reproductive health. These usually manifest in exposure and the risk of contracting sexually transmitted diseases (STDs), unwanted pregnancies, illicit drugs and high school dropout rate. The problems are attributed to the fact that adolescents lack information on sex education and sexuality. Again, they have few options of acquiring family planning services (Orubuloye and Caldwell, 1994; Jegede, 1997; Onifade, 1999; Babatola and Adegbola, 1999).

Therefore, adolescents face the risk of sexually transmitted infections including HIV/AIDS infections, among others. These risks are increased by social change and modernization as well as new technological and communication revolutions. Such as access to cybercafé, pornographic materials and of course, exposure to foreign culture through cable and satellite television programmes, may have made adolescents in Nigeria vulnerable due to exposure to media sexual contents early in their lives than counterparts who do not have access to these media contents.

To what extent do the media influence the sex behavior of adolescents? This is because studies on adolescents' sexuality (WHO, 1993; Akinyele and Onifade, 1996; Adegbola and Babatola, 1999) point out that changes in sexual and social norms have increased the risk of sexually transmitted infections (STDs). Also, exposure to explicit mass media content may increase the risk of early sex and contracting STDs among 
adolescents. In Nigeria, the increased risky sexual behaviour among adolescents has become worrisome. Cases of STDs and unwanted pregnancy among adolescents have not abated despite the national policy on adolescent reproductive health (Guardian Newspaper, Jan. 28, 1997). This may be so because, children are introduced to an array of information through the mass media even before the get to school age. Therefore, the media, especially television and the internet may bring children into a complex adult world early enough and may provide the impetus for children to ask the meaning of actions and works they would not yet have heard or read about without the television (Meyriwitz 1985; Biagi 2003).

The implication of this situation is that adolescents while they were children had begun to develop the intellectual and critical capacity to know what is not real. They may have already confronted, the world through the media. The mass media, through information and communication technologies have usurped the responsibilities of parents and may have exposed adolescents to foreign cultures, norms, social values. Above all, the media, especially, television may have become the newest "baby sitters" taking children away from their parents, providing social interactions and care needed by the children while their parents now work everyday to earn a living.

The study tried to examine and provide information on the influence the mass media (Newspaper, Magazines, Radio, Television and the new media "Internet") on the sexual behaviour of adolescents using secondary school students in Owerri Municipal as a reference. The study examined the relationship between the exposure to the media sexual contents and the sexual behavior of the selected adolescents in Imo State.

Therefore, the study tried to:

1. Investigate the extent of premarital sexual behavior of adolescent Students in Owerri Municipal.

2. Find out whether the exposure to explicit mass media contents influence premarital sexual behavior among the identified adolescents.

3. To ascertain specific areas of sex behaviour of the adolescent students that can be attributed to exposure to media sexual contents.

Research questions:

RQ 1: What is the level of premarital sex behavior among adolescent students in Owerri?

RQ 2: What is the level of premarital sex exposure of adolescents as a result of sex content of the media?

RQ 3: What specific sex behavior of the adolescent students can be attributed to media sex contents?

\section{Mass media influence and young people}

Mass media which include newspapers, radio television and internet have an immense impact on young minds. With the advent of the internet, television definitely has got a partner in the role of visual stimulation of the young minds. Unfortunately, the ideas canvassed in the media represent glamour, sexual satisfaction and promiscuity, comedic vulgarity, violence and immediate satisfaction of sexual needs (Pecora et al., 2007). However, it has been noted that the role of religion and spirituality in the lives of children and young people has been reduced by the presence of the glamourous media contents. Most studies show that while some programmes such as educational programmes benefit the children, they (children) have always been negatively affected by violent television programmes (Bledsoe and Cohen, 1993; Akinyele and Onifade, 1996; Akinnawo, 1995; Buckingham, 2000; Anderson, 2001; Brown et al., 2002). 
Negative effects of the mass media on children is well-researched (Chapin, 2002; Van-Evra, 2004) and as well as documented by different scholars (Wimmer and Dominick, 2003; Pecora et al., 2007). To this effect, the media have been accused of being responsible for reinforcement of ethnic, occupational, age gender, religion, sex-role stereotypes (Berry, 2001; Signorielli and Kahlenberg, 2001; Brown et al., 2002; Strauburger and Wilson, 2003). Hence, it has always been concluded that the media, especially television have promoted negative behavioural tendencies such as aggression and sexual pervasiveness among young people (Bushman and Huemann, 2001; Johnson et al., 2002; Grant, 2003; Murray, 2007). Early social researchers have questioned the nature of socialization children should get in an industrialized society - open or guided one (Clausen, 1968; Lippitt, 1968). There have been the clamour for pro-social media programmes aimed at promoting traditional values such as extended family, school, neighbourhood and local community (Dumova, 2008).

Therefore, it has become a question of the right to choose as contained in democratic ethos and the need to control, to some extent, such choice of information and entertainment, especially for young people (Araonye and Oladapo, 1999; Babatola and Adegbola, 1999; Bushman and Huemann, 2001; Agha and Rosen, 2002). Hence, communication scholars tried to research into the role and effects of the media on the child's socialization process (Rosengren, 2000; Van-Evra, 2004). However, today's young people are confronted with a lot of greater opportunities and challenges to the decisions than any period in human history (Firestone, 2003). Hence, parents are having difficulties raising children now than was the case decades ago. Some researchers suggest that adolescents with anti-social tendencies are drawn to television programmes and films containing violent actions or adventure themes (Belting, 1998; Davidson et al., 2003). Dumorva et al. (2008) conclude that recent developments in video production and the transition of television to the digital format have created an opportunity to consider prosocial television as a genre of TV programming designed to promote socially trusted behavior and assist in the socialization of youths. Hence, the authors argue that television in particular, can successfully promote social behavior to children and adolescents in society.

Therefore, there is high agreement among social scientists and media experts that socialization constitutes a very important role of the mass media and that society needs the younger generation to becoming productive and responsible members of society (Melin, 2006). However, the ways and extent of media involvement in such socialization have remained subjects of debates among both social scientists and media experts.

\section{The mass media and sexual behaviour of adolescents}

The adolescent reproductive health problems normally encountered by the health personnel include sexually transmitted infections (STIs) (like gonorrhea, syphilis, fungal Trichomonas and Chlamydia infection) and contraceptive problems (Omololu and Adeyefa, 1996). Several scholars such as Onifade (1999), Pistella and Bonati (1998) and Omololu and Adeyefa (1996) identified mass media as a social variable that influences sexually transmitted infections among adolescents. Similarly, United Nations Fund for Population Activities (Akinfeleye et al., 1998) reported that adolescents in East and South Asia various sources of information on sexuality and Sexually Transmitted Infections (STI) to include; comics and newspapers (print media), radio and television among others. However, they state that the messages did not give any clear picture on consequences of irresponsible sexual behavior, sexually transmitted infections among others.

According to Grant (2003) with the information age exploding through television, music, videos, video games and the internet, there is growing concern about whether adolescents exposure to sexual contents from media sources may have effects on their sexual behavior and attitude. This is because the content of the media, especially 
television, can be an instrument of socialization of our society as watching television is highly linked with most children's early development (Buckingham, 1993). Agha and Rosen (2002) note that mass media campaigns have been used in social marketing programs designed to prevent HIV infections by changing sexual behavior. Similarly, Thapa and Mishra (2002) are of the opinion that the mass media have been effective in informing urban youths about such social and health issues as drug addiction, HIV/AIDs, family planning, domestic violence and girl-trafficking. Also, Fielder (2003) has indicated that the straight talk foundation in Uganda has through multimedia communication programme consisting of publications, a radio programme, school visits and counseling promoted sexual and reproductive health and behavior change among adolescents. Studies abound that have examined the relationship between exposure to explicit media content and sexually pervasivebehaviour in adolescents (Lo et al., 1999) relationship between sexual violence and pornography (Bergen and Bogle, 2000); viewing of sexually explicit videos and attitudes towards feminism and rape (Davies, 1997).

Davidson et al. (2003) has argued that while the media offer the young people many opportunities to learn and be entertained, how young people interpret media images and messages contribute to a number of public health concerns that include risky sexual behavior. Akindele and Onifade (1996) and WHO (1993) found that the exposure to sexual message from the mass media coupled with the relaxation of social mores enhance pre-marital sex among the adolescents. Consistently, youths rank media as one of their leading sources of information on sex and sexuality (Davidson et al., 2003). Yet the media often portray sexual behaviour without highlighting the consequences of unintended pregnancy, HIV/AIDs infections or other sexually transmitted infections (STIs). However, Chapin (2002) points out that media critics complain about adolescents' exposure to sexy television popular music, while developmental transition leads to increased information seeking that make them seek information sources other than their parents. This, in effect, accounts for the link between sexy media contents and adolescents' sexual development (Lo et al., 1999; Thapa and Mishra, 2002). This study recognizes the need for adequate sex education through the mass media as a possible solution to protect adolescents from risk of early sex and sexually transmitted infections (STIs) among others. It also underscores the inclination of African society to cultural norm on sexuality, which portrays sex as a 'preserve for adults' (Jimoh, 1993; Jegede, 1997;).

\section{Methodology}

\section{Theoretical framework}

This work is anchored on two theories social cognitive and social learning theories. The social cognitive theory is predicted on the fact that people may tend to model or copy the behaviour they see in the media. Hence the modeling occurs in two ways: there is the initiation of behaviour which is a direct replication of an observed behaviour and also there is the identification, which is a special type of imitation where the observer do not copy exactly what they see in the media. But may make a more generalized but related response (Baran, 2001; Dominick, 2009) identification is harder to see and study, it can used to explain audience reaction and behavoural imitation especially, using television programmes. Social cognitive theorists demonstrated that initiation and identification are products of three processes namely, observational learning which is acquiring new behaviour by seeing others behave in the same manner, inhibitory effects, which entails seeing good people surfer for behaving well and disinhibitory effects, meaning seeing a model rewarded for not behaving well and this may increase the likelihood of misbehaving in the observers (McQuail, 2008; Vivian, 2009).

The second theory used in this study is the observational learning theory which is called social learning theory. The theory indicates that the observers of behaviour can be 
affected by the positive or negative consequences called vicarious reinforcement or vicarious punishment of models behaviour (Asemah et al., 2017). This theory was developed by Bandura (1959), to explain the types of learning where direct reinforcement is not the causal mechanism rather where social element can lead to new learning among media audience. Social learning has been used to explain how media audience learn behaviour through observing others, especially, in the media. Hence it is concerned with observation learning process among people. The process of social observational learning include Attention memory, Initiation and motivation. These theories can be used in explaining the extent to which the media can likely influence the sexual behavior of adolescents in Imo state. Hence exposure to sex and explicit sexual contents in the media can lead the the students adolescent to copy such sexual acts.

\section{Study design}

The study adopted a survey and interview schedule methods. It used both descriptive and analytical methods to examine and explain the influence of the media on adolescent sexual knowledge and behavior, with particular reference to adolescents (students) in Owerri Municipal (urban). The data for the study was obtained through primary and secondary sources, using semi-structured questionnaire and interview, The secondary data were collected through literature review. The study area involved Owerri, the capital city of Imo State in South-East Nigeria. The study population is made up of 3,849 adolescents students within ages of 10-19 years, who were in the fives secondary schools where a sample of 100 adolescent respondents were drawn, using a simple random sampling of 5 secondary schools. A sample frame consisting all secondary schools in Owerri urban was obtained from Imo State Ministry of Education, Owerri, in 2016, when the study was carried out. The sample consist of two all-boys schools, two all-girls schools a one co-educational (mixed) school. This allowed for equal representation of all the sexes. Twenty adolescents were randomly selected from each of the five secondary schools. The questionnaire contained both open-ended and close-ended questions and were personally administered by the researchers. The data analysis was presented using distribution tables, percentages and average (arithmetic mean), while chi-square $\left(\mathrm{X}^{2}\right)$ test was used to test the hypothesis.

The variables measured include age, religion and influence of the mass media on sex awareness and behavour. The independent and dependent variables were taken care of. The media organizations in Owerri included in the study are: Imo Broadcasting Corporation (IBC) with Orient FM and Orient Television Stations, NTA Channel 24 Owerri, Heartland FM, Hot FM and Zandas FM. Also, the State can boast of an array of National and local newspapers, brought in every morning from Lagos (the Commercial Centre of Nigeria). Interview sessions involving the media practitioners drawn from the selected media in Owerri were conducted.

\section{Results}

The results obtained from the field work were analyzed and interpreted using simple statistical techniques such as frequency tables, percentages and average (where necessary). The 100 copies of questionnaire administered to the adolescent students in Owerri Urban were successfully completed and returned. The response rate therefore, is hundred percent.

\section{RQ 1: What is the level of premarital sex among adolescent students?}

Table 1 indicates that the mean age for first sex experience was 17.8 years. Specifically, 9.3\% of the adolescents had their first sexual encounter between the age of 11 and 13; years, 53.7\% had sex between 14 and 16 years while $37 \%$ had sex between 17 and 
19 years. Data show that the sexually active male adolescents had their first sexual encounter at an average age of 17.5 years. While their female counterparts had theirs at an average age of 16.35 years. Hence, our informants and respondents all agreed on the existence of premarital sex among adolescent students in Owerri. They explained that due to the metropolitan nature of Owerri, youths are easily influenced by their peers and the media, especially, the internet from which they view obscene pictures. This is in line with the view of Thapa and Mishra (2002) that media exposure by youths can influence their behavior either positively or negatively depending on such media contents. Specifically, a key informant (journalists, with a national newspaper) said thus: "youths are within the impressionable age, their perceptions of maturity is about sex, and they think the only way they can be recognized grown ups is to involve in premature sex.

Table1. Existence of Premarital Sexual Activities among Adolescent Students in Owerri.

\begin{tabular}{|c|c|c|}
\hline Variables & Frequency & Percentage \\
\hline $\begin{array}{l}\text { Ever had sex } \\
\text { Yes } \\
\text { No }\end{array}$ & $\begin{array}{l}56 \\
44 \\
\end{array}$ & $\begin{array}{l}56 \% \\
44 \% \\
\end{array}$ \\
\hline $\begin{array}{l}\text { Ever had sex by gender } \\
\text { Male } \\
\text { Female }\end{array}$ & $\begin{array}{l}36 \\
20\end{array}$ & $\begin{array}{c}61 \% \\
38.7 \% \\
\end{array}$ \\
\hline $\begin{array}{l}\text { Age at first sex affair }(\mathrm{N}=54) \\
11-13 \\
14-16 \\
17-19\end{array}$ & $\begin{array}{c}5 \\
29 \\
20\end{array}$ & $\begin{array}{c}9.3 \\
53.7 \\
37.0\end{array}$ \\
\hline Average age $(\mathrm{x})$ & 17.8 years & \\
\hline $\begin{array}{l}\text { Age at first sex by gender } \\
\text { Male }(\mathrm{N}=34) \\
11-13 \\
14-16 \\
17-19\end{array}$ & $\begin{array}{c}5 \\
18 \\
11\end{array}$ & $\begin{array}{l}14.7 \\
52.9 \\
32.4\end{array}$ \\
\hline Average age $(\mathrm{x})$ & 17.5 years & \\
\hline $\begin{array}{l}\text { Female }(\mathrm{N}=20) \\
14-16 \\
17-19\end{array}$ & $\begin{array}{c}11 \\
9\end{array}$ & $\begin{array}{l}55 \% \\
45 \%\end{array}$ \\
\hline Average age $(\mathrm{x})$ & 16.35 years & \\
\hline $\begin{array}{l}\text { Had information about health problem if not } \\
\text { sexually active }(\mathrm{N}=100)\end{array}$ & & \\
\hline $\begin{array}{l}\text { Yes } \\
\text { No }\end{array}$ & $\begin{array}{l}61 \\
39 \\
\end{array}$ & $\begin{array}{l}61 \% \\
39 \% \\
\end{array}$ \\
\hline
\end{tabular}

Also, data reveal that out of the total population of 100 adolescent student respondents, about $61 \%$ stated that they were informed by their friends and peers that they might have health problems if they were not sexually active before age 20 . This however, is against 39\% that said they have not received such sex information from any source. In summary, more than half of the adolescent students in Owerri Urban have had sex, with three fifth of the first timers being males. The mean age at first sexual affairs of the adolescents is 17.8 years, though the sexually active male adolescents had their first sex at a comparatively younger age, than their female counterparts. 


\section{RQ 2: What is the level of premarital sex exposure of adolescent as a result of explicit sex content of the media?}

Table 2 show that $100 \%$ of the adolescent student respondents in Owerri Urban have heard about premarital sex. This however, contrasts with $1 \%$ that has no such knowledge. Also, the respondents (99\%) of the adolescent student respondents say they have knowledge about pregnancy and prevention through contraceptives. The notable contraceptives known to the adolescents are condom and pills such as while quinine. Similarly, $59.3 \%$ of the adolescents had , heard through the media ,that contraceptives can protect the users against sexually transmitted infections and unwanted pregnancy. While $40.7 \%$ indicated that the media did not induce them to use contraceptives to prevent unwanted pregnancy. Data in the charts above and Table 2 reveal that $24.6 \%$ of the adolescents heard about the advantages of safe sex through radio and television, $22.9 \%$ heard of it from close friends or peer groups, $18.6 \%$ heard of it from school or class mates , $10.2 \%$ heard from older brothers/sisters/other relations, $8.5 \%$ read about it from newspapers and magazines, $6.5 \%$ heard of it from parents/guardians, 5.6\% heard from internet, while $3.1 \%$ said they heard from church. In brief, about $33.1 \%$ which is one third of the total respondents indicated that mass media (radio/TV and newspaper/magazine) may have influenced their sexual behaviour.

Table 2. Sources of exposure to premarital sex information.

\begin{tabular}{|c|c|c|}
\hline Variable & Frequency & Percentage \\
\hline \multicolumn{3}{|l|}{ Knowledge of Premarital sex } \\
\hline Yes & 99 & $99 \%$ \\
\hline No & 1 & $1 \%$ \\
\hline \multicolumn{3}{|c|}{ Heard about sex and the use of contraceptives against unwanted pregnancies $(\mathrm{N}=100)$} \\
\hline Yes & 99 & $99 \%$ \\
\hline No & 1 & $1 \%$ \\
\hline \multicolumn{3}{|c|}{ Source of information about sex and contraceptives } \\
\hline Parents/Guardians & 23 & $6.5 \%$ \\
\hline Older family members/other relations & 36 & $10.2 \%$ \\
\hline Radio/TV & 87 & $24.6 \%$ \\
\hline Close friends & 81 & $22.9 \%$ \\
\hline School mates & 66 & $18.6 \%$ \\
\hline Church & 11 & $3.1 \%$ \\
\hline Internet & 30 & $5.6 \%$ \\
\hline Newspaper/Magazines & 30 & $8.5 \%$ \\
\hline \multicolumn{3}{|l|}{ Contraceptive Use $(\mathrm{N}=54)$} \\
\hline Yes & 32 & $59.3 \%$ \\
\hline
\end{tabular}

RQ 3: What specific sex behavior of the adolescent students can be attributed to mass media contents?

Data (Table 3) show that almost three fifth (59.3\%) of the sexually active adolescents have heard about sexual acts as opposed to $40.7 \%$ that have not. Among those who have heard about sex and sexual acts, a substantial proportion said they were introduced to sex and sexual activities by their peers, sex partners, mass media and older brothers or sisters. Hence, almost all the adolescent respondents (99\%) have heard about sex before engaging in it. A preponderant portion (33.1\%) of those who heard about sex and sexual acts did so through the media. Unfortunately, the knowledge about protective is not wide spread among the respondents as only $59.3 \%$ of the sexually active 
adolescents used any form of protection. However some of the respondents indicated that they were introduced to protective sex not only by the media but also by their sex partners.

Table 3. Influence of the media on the sexual behavior of the adolescents in Owerri Urban.

\begin{tabular}{|l|c|c|c|}
\hline \multirow{2}{*}{ Influence of the media } & \multicolumn{2}{|c|}{ Ever had sex } & \multirow{2}{*}{ Total } \\
\cline { 2 - 3 } & Yes & No & 55 \\
\hline Yes & $44(29.2)$ & $11(25.8)$ & 45 \\
\hline No & $9(23.9)$ & $36(21.1)$ & 100 \\
\hline Total & 53 & 47 & \\
\hline
\end{tabular}

\section{Testing of hypothesis} Therefore:

The hypothesis was tested using Chi-square $\left(\mathrm{X}^{2}\right)$ to know the extent they are valid.

$$
\mathrm{X}^{2}=\frac{\sum(\mathrm{Oi}-\mathrm{Ei})^{2}}{\mathrm{Ei}}
$$

Where:

$\sum=$ Summation

Oi $=$ Observed frequency

$\mathrm{Ei}=$ Expected frequency

\section{Decision rule for $\mathrm{X}^{2}$}

When the calculated $\mathrm{X}^{2}$ value $\left(\mathrm{cal} \mathrm{X}^{2}\right)$ is greater than the tabulated $\mathrm{X}^{2}$ value $\left(\operatorname{tab} \mathrm{X}^{2}\right)$, hence the difference between the observed frequency and expected frequency is statistically significant. Therefore, we reject the null hypothesis $\left(\mathrm{H}_{0}\right)$ and accept the alternative hypothesis $\left(\mathrm{H}_{1}\right)$. But if the calculated $\mathrm{X}^{2}\left(\mathrm{cal} \mathrm{\textrm {X } ^ { 2 } )}\right.$ is less than the tabulated $\mathrm{X}^{2}$ $\left(\operatorname{tab} X^{2}\right)$, the difference is statistically not significant, we accept the null hypothesis $\left(\mathrm{H}_{0}\right)$ which states that the mass media do not significantly influence the sexuality of adolescent students in Owerri.

\section{Hypothesis 1}

$\mathrm{H}_{0}$ : The mass media do not significantly influence the sexuality of adolescent students in Owerri.

$\mathrm{H}_{1}$ : The mass media do significantly influence the sexuality of adolescent students in Owerri.

\section{Decision rule}

$$
\begin{aligned}
& X^{2}=\frac{(\mathrm{Oi}-\mathrm{Ei})^{2}}{\mathrm{Ei}}=\frac{(\mathrm{Oi}-\mathrm{Ei})^{2}}{\mathrm{Ei}}+\frac{\left(\mathrm{O}_{2}-\mathrm{E}_{2}\right)^{2}}{\mathrm{Ei}}+\frac{\left(\mathrm{O}_{4}-\mathrm{E}_{4}\right)}{\mathrm{Ei}} \\
& X^{2}=\frac{(44-29.2)^{2}}{29}=\frac{(11-25.8)^{2}}{25.8}+\frac{(9-33.9)^{2}}{33.9}+\frac{(36-21.1)}{21.1}
\end{aligned}
$$

Cal $\mathrm{X}^{2}=\quad 35.8$ degree of freedom $(\mathrm{df})=(\mathrm{r}-1)(\mathrm{c}-1)=1$ 
The cal $\mathrm{X}^{2} 35.8$ is greater than the tab $\mathrm{X}^{2} 3.84$ at $\mathrm{X}=0.05$, This shows that the difference between the observed frequency of the level of influence of mass media on sexual behavior of adolescent students in Owerri Urban and the expected frequency is statistically significant. Therefore we accept the null hypothesis $\left(\mathrm{H}_{0}\right)$ that states that the mass media do not significantly influence the sexuality of adolescent students in Owerri Urban.

The results show that equal numbers of adolescent students of both genders with mean age of 17.41 years were sampled in Owerri Urban. The respondents were all Christians with little more than half of the adolescents who have had sex were three-fifth males. The mean age for first sex is 17.8 years though the sexual active females had their first sex at an earlier age (16.35) than their male counterparts (17.5 years). Contrary to popular belief and other studies on behavior and media, (see Bushman and Huesmann, 2001; Johnson et al., 2002; Murray, 2007) the media did not have significant influence sexual behavior of adolescents in Owerri at 0.05 . This is perhaps due to the inaccessibility of some of the adolescent students to the media while in school hostels (Adeokun et al. 2009). Other significant factors identified that affect sexual behavior include; behavior of parents and peer influences. Strict parents in Nigeria exert much influence on the age at which their children have first sex. Also, the findings showed that extended family member and peer group influence sex decision of the adolescents. In most communities in Nigeria the fact that parents still receive gifts from the in- laws if their daughters marry as virgins can override any media influence to do otherwise.

Also, results show that almost all the adolescents (99\%) have heard about contraceptives through the media. Hence an overwhelming proportion of them said they heard about safe sex through the media. However, contraceptives and condom use is not too high among the respondents. To this effect, only $59.3 \%$ of sexually active adolescent respondents said they use them. This may be supported by the fact that Broadcasting Organization of Nigeria (BON) regulates advertisements on condoms and contraceptives. Also, the study shows that mass media do not significantly influence awareness about contraceptives use against sexually transmitted infection amonge the adolescents (Buckingham, 2000).

\section{Conclusion}

Based on the results, we conclude as follows:

1) Adolescent students in Owerri Urban engage in premarital sexual activities at an average age of 17.8 years, with more than half of the sexually active persons being males.

2) The mass media do not significantly influence the sexual behaviour of the adolescents in Owerri.

3) The mass media, to some extent, do influence the awareness and the practice of safe sex among the sexually active adolescents in Owerri Urban.

We recommend as follows:

1. Government could strictly sanction the accessibility of adolescents to certain media messages, especially those on sex.

2. The influence of parents and peer influence need to be given priority attention in adolescents' sexual behavior discussions are held in Nigeria. 
3. The mass media could be made to provide filtered and strict messages on sex education and sexual behaviour.

\section{Conflict of interests}

The author declares that they do not have any conflict of interests.

\section{References}

Adegbola, 0.; Babatola, O. Premarital and extramarital sex in lagos-Nigeria. In: Orubuloye, I. O.; Caldwell, J. C.; Ntozi, J. P. M. (Eds.). The continuing HIV/AIDs epidemic and Africa: Responses and coping strategies. Canberra, Australia: Health Transition Centre, 1999.

Adeokun, L. A.; Ricketts, O. L.; Ajuwon, A. J.; Ladipo, O. A. Sexual and reproductive health knowledge behaviours and education needs in school adolescents in Nigeria. African Journal of Reproductive Health, v. 13, no. 4, p. 37-49, 2009.

Agha, S.; Rosen, R. V. Impact of mass media campaigns on intentions to use the female condom in Tanzania. International Family Planning Perspectives on Sexual and Reproductive Health, v. 28, no. 3, p. 151-158, 2002.

Akinfeleye, R.; Charle, J.O.; Omideyi, A. K.; Fayisetan, B. (Eds.). Socio-cultural factors affecting attitude and behaviour regarding population and family life issues in Nigeria. New York: UNFPA - United Nations Fund for Population Activities, 1998.

Akinnawo, E. O. Sexual networking, STDs and HIV/AIDS transition among Nigerian police officers. Health Transition Review, v. 5, p. 113-121, 1995.

Akinyele, I. O.; Onifade, I. O. Trends in social behaviour among secondary school adolescents in Ibadan. Ibadan: Institute of African Studies, University of Ibadan, 1996. (Occasional publication, 5).

Anderson, D. Early childhood television viewing and adolescent behaviour. Boston: Blackwell, 2001.

Araonye, M. 0.; Oladapo, O. Sexuality and contraception among Nigerian adolescents and youths. African Journal of Reproduction Health, v. 2, p. 142-150, 1999.

Asemah, S.; Nwammuo, A.; Nkwam-Uwaoma, N. Theories and models of communication. Jos: Jos University Press, 2017.

Babatola, 0.; Adegbola, 0. Generational controversy on sexual activity in the context of the AIDS epidemic, evidence from Lagos. In: Orubuloye, I. O.; Caldwell, J. C.; Ntozi, J. P. M. (Eds). The continuing HIV/AIDs epidemic and Africa: Responses and coping strategies. Canberra, Australia: Health Transition Centre, 1999.

Baran, S. J. Introduction to mass communication media literacy and culture. London. May Field Publishing, 2001.

Bandura, A. Adolesent agression. New York: Ronald Press, 1959.

Belting, H. The German and their art: A troublesome relationship. Yale: Yale University Press, 1998.

Bergen, R.; Bogle, K. Exploring the connection between pornography and sexual violence. Violence and Victim, v. 15, p. 227-234, 2000. 
Berry, G. L. Developing children and multicultural attitudes: The systemic psychological influences of television portrayals in a multimedia society. Cultural Diversity and Ethnic Minority Psychology, v. 9, no. 4, p. 360-366, 2001. https://doi.org/10.1037/10999809.9.4.360

Biagi, S. Media impact: An introduction of mass media. Wadsworth: Publishers America, 2003. v. 1.

Bledsoe, C. H.; Cohen, B. Social dynamics of adolescents fertility in Sub-Saharan Africa. Washington, D.C.: National Academic Press, 1993.

Brown, J. D.; Steele, J. R.; Walsh-Childer, S. K. (Eds.). Sexual teens, sexual media investigating media influence on adolescent sexuality. Mahwah, NJ: Erlbaum, 2002.

Buckingham, D. Making sense of the media: From reading culture. London: John Wiley Press, 1993.

Buckingham, D. After the death of childhood: Growing up in the age of electronic media. Malden, M.A.: Blackwell, 2000.

Bushman, B. J.; Huemann, L. R. Effects of televised violence on aggression. In: Singer, D. G.; Singer, J. L. (Eds.). Handbook of children and the media. Thousand Oaks, CA: Sage, 2001. p. 223-354.

Chapin, J. R. Adolescent sex and mass media: A developmental approach. Canada: Adole, 2002.

Clausen, J. A. Socialization and society. Boston, Little Brown: Social Science Research Council, 1968.

Davidson, S.; Lefebvre, A; Morris, P.; Nieman, P.; Swift, C. Putting media under the microscope: Understanding and challenges media influence on the health and wellbeing of children and youth. Paediatrics \& Child Health, v. 8, n. 5, p. 265-266, 2003.

Davies, K. Voluntary exposure to pornography and men's attitudes towards feminism and rape. Journal of Sex Research, v. 34, p. 131-137, 1997.

Dominick, J. R. The dynamics of mass communication. 10. ed. New York: McGraw-Hill Higher Education, 2009.

Dumova, T. Prosocial content in a local children's television programme: A case study, 1972-2002. International Journal of Technology, Knowledge \& Society, v. 2, no. 8, p. 129-140, 2007.

Fielder, A. A. Information dissemination to young people. Kampala, Uganda: The Straight Talk Foundation, 2003.

Firestone, J. M. The new knowledge management: A paradigm and its problems. Alexandria, VA: Knowledge Management Consortium International, 2003. Available from: <http://www.kmci.org/media/Firestone-tnkmparadigm.pdf>. Accessed on: Jan. 12, 2020.

Grant, C. Teens, sex and the media: Is there a connection? Paediatrics \& Child Health, v. 8, no. 5, p. 285-286, 2003. https://doi.org/10.1093/pch/8.5.285

Guardian Newspaper, Jan. 281997.

Jegede, A. S. Family planning information sources and media exposure among Nigerian male adolescents: A case study of Ekiti South West LGA of Ondo State. Dakar, Senegal: Union of African Population Studies, 1997. (Study report, 28). 
Jimoh, A. Narrative research approach to adolescents sexual behaviour. The Guardian, Thursday, July 15, 1993.

Johnson, J.; Cohen, P.; Smailes, E.; Kasen, S.; Brook, J. Television viewing and aggressive behaviour during adolescence and adulthood. Science, v. 295, no. 5564, p. 2468-2471, 2002. https://doi.org/10.1126/science.1062929

Lippitt, G. Addiction, assessment and treatment with adolescent. Havard: Havard Business, 1968.

Lo, V.-H.; Neilan, E.; Sun, M.-P.; Chiang, S.-I. Exposure of Taiwanese adolescents to pornographic exposure media and its impact on sexual attitudes and behaviour. Asian Journal of Communication, v. $9, \quad$ p. 50-71, 1999 . https://doi.org/10.1080/ 01292989909359614

McQuail, D. Mass communication theory. London: SAGE Publishers, 2008.

Melin, L. Understanding strategies in family business context. Cheltenham: Edward Elgar, 2006.

Meyriwitz, J. No sense of place: The impact of electronic media on social behaviour. NewYork: Oxford Univeristy Publishers, 1987.

Murray, J. P. TV violence research and controversy. In: Pecora, N.; Murray, J. P.; Wartella, E. (Eds.). Children and television: Fifty years of research. Mahwah, NJ: Erlbaum, 2007. p. 183-204.

Nass, G. D.; Libby, R.; Fisher, M. P. Sexual choice. Monetary: Wadsworth Health Science Division, 1981.

Omololu, F; Adeyefa, I. Family background, sexual behaviour and HIV/AIDS. New York: Wiley \& Sons, 1996.

Onifade, I. Unmet reproductive health needs of adolescents: Implications for HIV/AIDS prevention in Africa. In: Orubuloye, I. O.; Caldwell, J. C.; Ntozi, J. P. M. (Eds). The continuing HIV/AIDs epidemic and Africa: Responses and coping strategies. Canberra, Australia: Health Transition Centre, 1999.

Olubuloye, I. 0.; Caldwell, J. C. Eduaction and multiple sexual partners: The case of adolescence in informal settlement of Nairobi. Nairobi, Kenya: Population Studies and Research Institute of Nairobi, 1994.

Pecora, N.; Murray, J. P.; Wartella, E. (Eds.). Children and television: Fifty years of research. Mahwah, NJ: Erlbaum, 2007.

Pistella, C. L.; Bonati, F. A. Communication about sexual behaviour among adolescent women, their families and peers. Families in Society, v. 79, no. 2, p. 206-211, 1998.

Rosengren, E. Communication: An introduction. London: Sage Publisher, 2000.

Saba, A. Y. Evaluation of knowledge practice and behaviour towards sexuality among secondary school students in Minna Municipality, Nigeria. Ibadan, Nigeria: University of Ibadan, 1995. (M. Ed. Project. Department of Physical and Health Education).

Signorielli, N.; Kahlenberg, S. Television's world of work in the nineties. Journals of Broadcasting and Electronic Media, v. 45, no. 1, p. 4-22, 2001. https://doi.org/ 10.1207/s15506878jobem4501_2

Strauburger, V. C.; Wilson, B. J. Children, adolescents and the media: Ten mistakes we have made and how to fix them. London: Sage, 2003 
Thapa, S.; Mishra, V. Mass media exposure among urban youth in Nepal. Asia-Pacific Population Journal, v. 18, no. 1, 2002.

Van-Evra, J. Television and child development. Mahwah, NJ: Erlbaum, 2004.

Vivian, J. The media of mass communication. 9. ed. Boston: Pearson Education, 2009.

WHO/UNAIDS. HIV prevention, treatment and support for people who use stimulant drugs. Washington: WHO/UNAIDS, 1997.

Wimmer, R.; Dominick, J. Mass media: An introduction. New York: Thomso Wadsworth 2003. 